\title{
Report of epibiont Thecacineta calix (Ciliophora: Suctorea) on deep-sea Desmodora (Nematoda) from the Andaman Sea, Indian Ocean
}

\author{
BABAN INGOLE ${ }^{1}$, RAVAIL SINGH ${ }^{1}$, SABYASACHI SAUTYA ${ }^{1}$, IGOR DOVGAL ${ }^{2}$ AND TAPAS CHATTERJEE ${ }^{3}$ \\ ${ }^{1}$ National Institute of Oceanography, Dona Paula (CSIR), Goa-403 004, India, ${ }^{2}$ Schmalhausen Institute of Zoology, B. Khmelnitsky \\ Street, 15, 01601 , Kiev, Ukraine, ${ }^{3}$ Indian School of Learning, ISM Annexe, PO-ISM, Dhanbad 826004, Jharkhand, India
}

\begin{abstract}
Suctorian epibionts Thecacineta calix attached on the cuticle of nematodes Desmodora sphaerica and D. pontica are reported here from the deep-sea hexactinellid sponge Pheronema sp. from the Andaman Sea (Indian Ocean). The epibiont T. calix is reported here for first time from the Andaman Sea.
\end{abstract}

Keywords: epibionts, suctorians, Thecacineta calix, deep-sea, nematodes, Desmodora, Andaman Sea, Indian Ocean

Submitted 2 October 2008; accepted 8 January 2010

\section{INTRDDUCTION}

Suctorian ciliates are common epibionts on benthic marine and interstitial invertebrates like harpacticoid copepods, nematodes, halacarid mites etc. (Jankowski, 1981; Dovgal, 1996; Dovgal et al., 2008). A number of suctorian ciliate ectocommensals have been observed occurring on the cuticle of various members of the family Desmodoridae (Allgen, 1952, 1955; Matthes, 1956). In the present study, suctorian ciliates have been recovered on the cuticle of two nematode species Desmodora sphaerica and $D$. pontica belonging to the Desmodoridae family isolated from the deep-sea sponge Pheronema sp. from the Andaman Sea. Scrupulous microscopic observations revealed suctorian epibionts are conspecific with Thecacineta calix. Thecacineta calix is reported here for first the time from the Andaman Sea.

\section{MATERIALS AND METHDDS}

As part of a deep-sea study of benthic biodiversity, sediment sampling was performed in the Andaman Back Arc Basin (Figure 1) during the RV 'Sonne' cruise (NIO-RVS-II, 17 October to 1 December 2007). Seabed samples were obtained by deploying a TV camera-guided grab (area: $0.6 \mathrm{~m}^{3}$ ) which consists essentially of a set of steel jaws with a video camera in the centre. It collected sediment and rock samples and transmitted pictures of the ocean floor to the deck unit. Some specimens of hexactinellid sponge were collected along with the sediment and rock samples taken from the upper slope of the Northern Seamount located off Nicobar

Corresponding author:

I. Dovgal

Email: dovgal_@voliacable.com
Island, $9^{\circ} 59^{\prime} 31.52^{\prime \prime} \mathrm{N} 93^{\circ} 57^{\prime} 15.48^{\prime \prime} \mathrm{E}$, from a water depth of $1301 \mathrm{~m}$. Upon collection, the sponges were carefully separated from the sediment and immediately preserved with absolute alcohol. In the laboratory, the sponge samples were washed carefully and the entire faunal community associated with sponge spicules were sorted out carefully and identified to the lowest possible taxa. All the nematodes were separated and fixed in $5 \%$ formalin. Nematodes were identified to genus/species level according to Platt \& Warwick (1983) and using on-line recent literature (www.nemys.ugent.be).

Measurements of ciliates were made using the computer program Scope Photo v. 2.0 for processing of digital images. For slide preparation the material was stained by Boehmer's haematoxylin and mounted in Canada balsam. Permanent slides of infested nematodes were deposited in the collections of the Department of Fauna and Systematics of Invertebrate Animals of the Schmalhausen Institute of Zoology, National Academy of Sciences, Ukraine and in the museum of Biological Oceanography, National Institute of Oceanography, Goa, India.

\section{RESULTS AND DISCUSSION}

Nematodes species Desmodora sphaerica and D. pontica, belonging to the genus Desmodora of the family Desmodoridae associated with a deep-sea hexactinellid sponge Pheronema sp., were used for the present study. A total of 71 specimens of nematodes belonging to six species were isolated from the deep-sea Pheronema sp. Of these, five (Desmodora sphaerica, D. pontica, D. schulzi, Desmodora sp.1 and Desmodora sp.2) belonged to the family Desmodoridae and one specimen could not be identified as it was damaged. Among these, D. sphaerica (17 individuals out of 71 specimens of nematodes collected) and D. pontica (12 individuals out of 71 specimens of nematodes collected) 


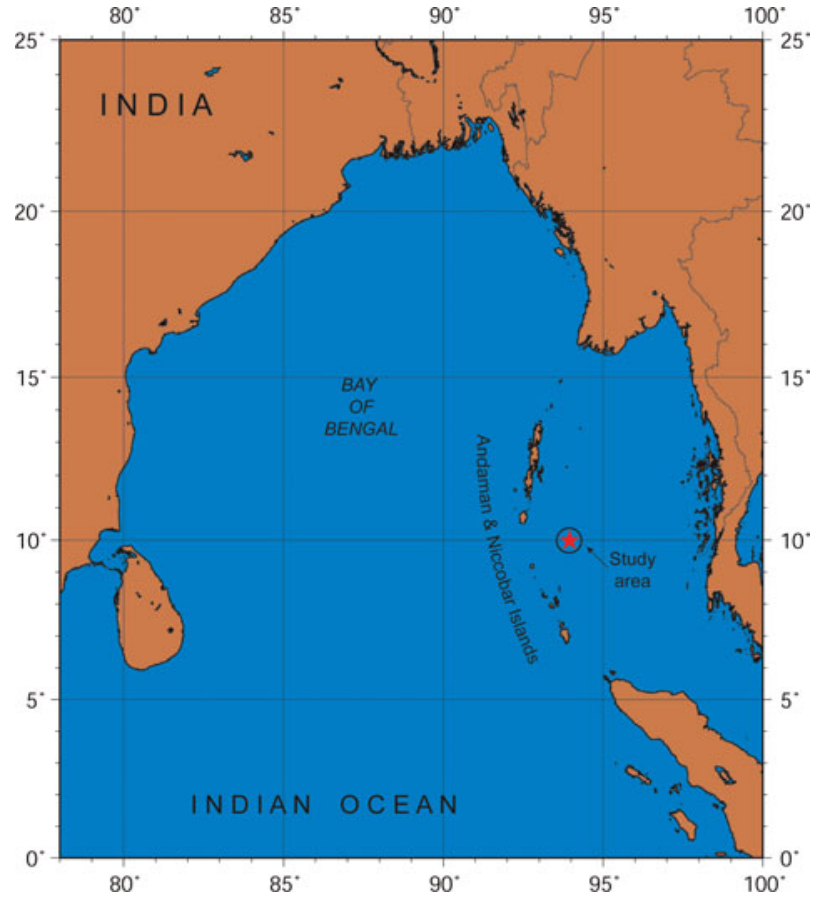

Fig. 1. Map showing sampling location (indicated with a star $\star$ ).

together made $\sim 41 \%$ of the nematode population. Among 17 individuals of $D$. sphaerica collected, 13 (76\%) were infested with suctorians and among 12 individuals of $D$. pontica 9 (75\%) were infested with suctorians. Among the infested D. sphaerica $54 \%$ were female and $46 \%$ were male; among the infested $D$. pontica $67 \%$ were female and $33 \%$ were male. The suctorians were mostly noticed on the tail region but a few specimens were also found in the mid-region.
The detailed taxonomic study of the suctorian revealed that they belong to the ectocommensal Thecacineta calix (Schröder, 1907). Thecacineta calix, a marine loricate suctorian ciliate with a single apical fascicle of tentacles, was described from marine nematodes (Schröder, 1907). Subsequently, (Collin, 1909) combined all known species that had a similar morphology into the genus Thecacineta. Later, (Matthes, 1956) investigated T. calix as epibionts on harpacticoid copepod Laophonte cornuta from the Mediterranean Sea. This epibiont is also reported from various meiobenthic organisms such as halacarid mites, harpacticoid copepods and nematodes.

\section{SYSTEMATICS}

Class suctorea Claparède et Lachmann, 1859

Subclass VERMIGENIA Jankowski, 1978

Order SPELAEOPHRYIDA Jankowski, 1978

Family THECACINETIDAE Matthes, 1956

Genus Thecacineta Collin, 1909

Thecacineta calix (Schröder, 1907) (Figure 2)

$$
\text { = Acineta calix Schröder }
$$

$=$ Thecacineta desmodorae Schulz

= Thecacineta subantarctica Allgen

= Thecacineta donsi Allgen

= Thecacineta paradesmodorae Allgen

$=$ Thecacineta laophontis Jankowski = Paracineta moebiusi Kahl

\section{DIAGNOSIS}

Marine loricate, suctorian. Cell body entirely fills the lorica and attached to their bottom. Lorica totally ribbed transversely. Apical part of body protrudes beyond lorica aperture. Up to 30 clavate tentacles with length about $90 \mu \mathrm{m}$ arise from upper body surface. Macronucleus large, oviform, located at the bottom of the cell body. With large contractile vacuole placed in basal body part usually near macronucleus.

A

B
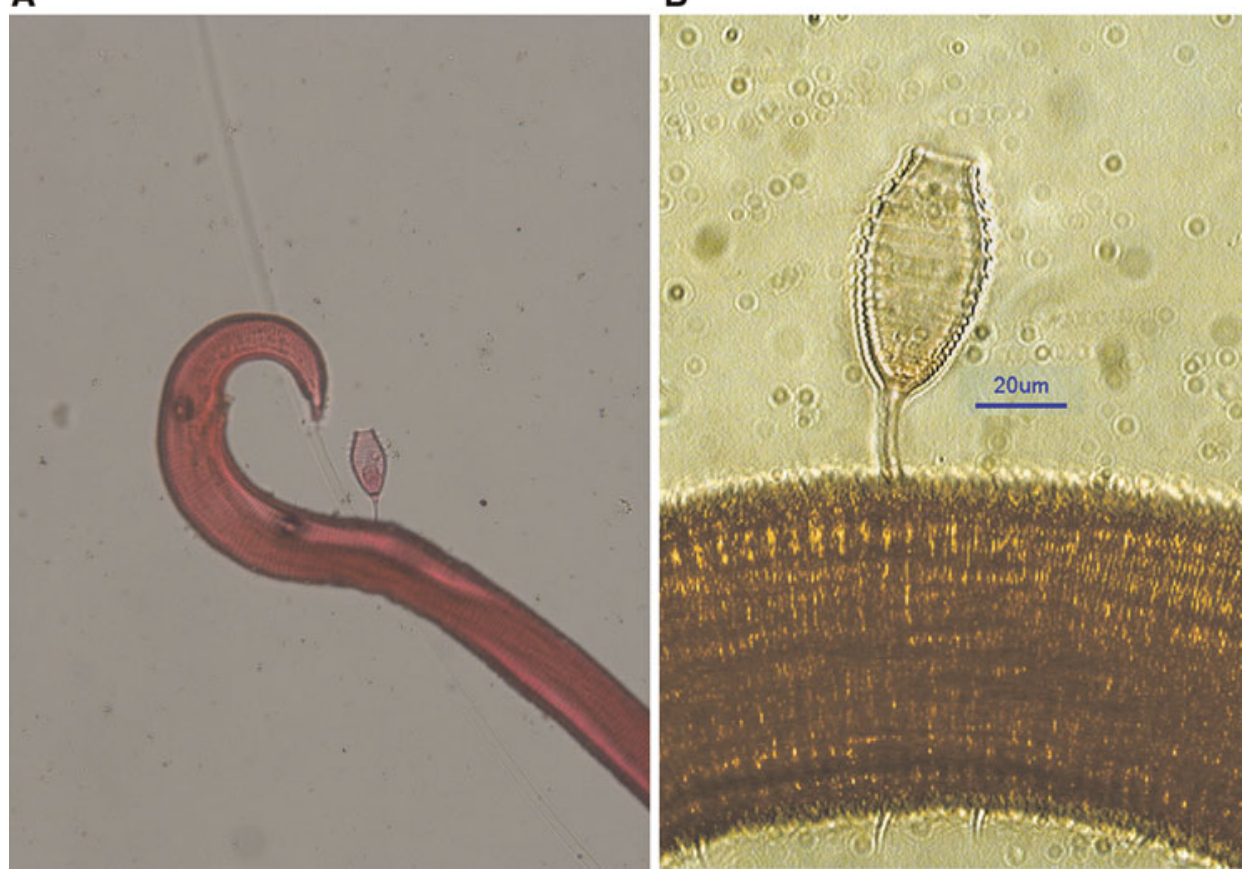

Fig. 2. (A) Thecacineta calix attached with Desmodora pontica from the Andaman Sea; (B) magnified view of Thecacineta calix attached with Desmodora from the Andaman Sea. 


\section{MEASUREMENTS}

Measurements $(\mu \mathrm{m})$ of four individuals from the Andaman Sea, in parentheses measurements of individuals from copepod host (after Matthes, 1956): body length 14-24 (47-49 under colonization of the copepod host); width in the middle of body $12-17$ (22-30 in copepod host); macronucleus diameter 6-8 (13-16 in copepod host); length of the lorica 44-60 (103-164 in copepod host), lorica width 25-26 $\mu \mathrm{m}$, stalk length 15-21 $\mu \mathrm{m}$, stalk thickness $1.5-3 \mu \mathrm{m}$.

\section{DISTRIBUTION AND HOST SPECIFICITY}

Earlier Thecacineta calix was reported as epibiontic on nematodes, crustacean copepods, halacarid mites from the Atlantic, Pacific, Antarctic and Indian Oceans (Kerguelen Island) (Schröder, 1907; Allgen, 1949, 1952, 1955; Matthes, 1956; Gelmboldt \& Dovgal, 2005; Dovgal et al., 2008). Among nematodes $T$. calix has been reported as epibiontic on Desmodora campbelli, D. microchaeta, D. odhneri, D. reducta, D. stateni, Acanthopharynx japonicas, Epsilonema symbioticum, E. poccilothrix and Paradesmodora sp. (Schröder, 1907; Steiner \& Hoeppli, 1926; Schulz, 1931; Steiner, 1931; Allgen, 1949; Matthes, 1956; Susetiono, 2006; Jankowski, 2007). The present report is the first to record T. calix from the Andaman Sea. Thecacineta calix also has been reported from fresh water in Thailand (Charubhun \& Charubhun, 2000), however, the latter find calls for further investigation because $T$. calix is a marine species.

\section{REMARKS}

In many cases the suctorians were attached close to the cloaca of the nematodes. Probably that observed location may be connected with the mode of reproduction of thecacinetid suctorians, including T. calix, by vermigemmic budding. The swarmers (migratory stages, devoid of ciliature, vermiform and unable to swim) are formed during reproduction. These swarmers crawl onto the new host over the surfaces of the copulating hosts, therefore, localization of the commensals near the zone of joining of copulating nematodes may possibly give priority to epibionts for expansion.

\section{ACKNDWLEDGEMENTS}

The authors wish to express their gratitude to the CSIR for financial support to the Net-Work project 'Indian Ridge studies'. We also thank the Director of NIO Goa for the facilities. We wish to acknowledge the team leader Dr Kamesh Raju and the entire 'Ridge Group' for excellent teamwork during the deep-sea cruises. Our special thanks to Dr K.R. Tabachnick, Russian Institute of Oceanology, Moscow for identifying the deep-sea sponge. This is contribution No. 4492 of NIO (CSIR) Goa.

\section{REFERENCES}

Allgen C.A. (1949) Uber zwei neue subantarktische Suctorien. Archiv für Zoologie 42, 1-3.

Allgen C.A. (1952) Uber zwei neue antarktische Suctorien aus dem Gracham Land. Kungliga Fysiografiska Sällskapets $i$ Lund Forhandlingar 21, 173-176.

Allgen C.A. (1955) Die Suctorien der scgwedischen Sudpolar-Expedition (1901-1903). Zoologischer Anzeiger 154, 36-48.

Charubhun B. and Charubhun N. (2000) Biodiversity of freshwater Protozoa in Thailand. Kasetsart Journal (Natural Science) 34, 486494.

Dovgal I.V. (1996) Keys for identification of tentaculous infusoria (Ciliophora, Suctoria) of the Ukrainian fauna. Vestnik Zoologii 2, Suppl., 42 pp.

Dovgal I., Chatterjee T. and Ingole B.S. (2008) An overview of suctorian ciliates (Ciliophora, Suctorea) as epibionts of halacarid mites (Acari, Halacaridae). Zootaxa 1810, 60-68.

Jankowski A.V. (1981) New species, genera and families of tentacled infusoria (class Suctoria). Proceedings of the Zoological Institute of Russia 107, 80-115.

Jankowski A.V. (2007) Review of taxa Phylum Ciliophora Doflein, 1901. In Alimov A.F. (ed.) Protista: handbook on zoology, part 2. St Petersburg: Nauka, pp. 415-993.

Matthes D. (1956) Suktorienstudien VIII. Thecacineta calix (Schröder 1907) (Thecacinetidae nov. fam.) und ihre Fortpflanzung durch Vermoid-Schwarmer. Archiv für Protistenkunde 101, 477-528.

Schröder O. (1907) Die Infusorien der Deutschen Sudpolar-Expedition 1901-1902. V. Drygalski, Deutscher Sudpolar-Expedition 1901-1903 Bd. IX, 349-36o.

Schulz E. (1931) Beitrage zur Kenntnis marinen Suctorien. I. Zoologischer Anzeiger 96, 95-99.

Steiner G. (1931) Die Nematoden der Deutshen Sudpolar-Expedition 1901-1903. V. Drygalski, Deutscher Sudpolar-Expedotion 1901-1903 Bd. XX. [Cited after Matthes, 1956.]

and

Susetiono P. (2006) Epibiosis Thecacineta calix (Protozoa, Ciliophora) pada meiofauna Paradesmodora sp. (Nematoda, Desmodoridae) dari perairan Indonesia. Oceana 31, 41-49.

\section{Correspondence should be addressed to:}

\section{Dovgal}

Schmalhausen Institute of Zoology,

B. Khmelnitsky Street, 15, 01601, Kiev,

Ukraine

email: dovgal_@voliacable.com 